\title{
The impact of the E- CRM (expected security and convenience of website design) on E- loyalty field study on commercial banks
}

\author{
Hadeer Helal M. Rashwan \\ Abdelaty Lasheen M. Mansi \\ Heba E. Hassan \\ Suez University, Egypt
}

\section{Keywords}

E-CRM, expected security, convenience of website design, E-loyalty, electronic banking satisfaction.

\begin{abstract}
This study aimed to investigate the micro-linkages between electronic customer relationship management (E-CRM) and electronic loyalty of customers, through electronic banking satisfaction as a mediator variable. specifically, the neglected roles for expected security, convenience of website design. To achieve the objectives of the study, four basic hypotheses were formulated, it's were tested using preliminary data collected through the survey list, Data was collected by a convenience sample, the sample of study consisted of (370) customer who representative of the community of customers of Egyptian commercial banks who dealing electronically, Data analysis and hypothesis testing have been depended on use methods of a structural equation modeling, confirmatory factor analysis, path analysis, and direct and indirect analysis by using the Bootstrap method, The study found a significant correlation between the dimensions of the E-CRM (expected security) and The intentions of repeat e-dealing and providing customers positive words to others, A significant correlation was found between the convenience of website design and providing customers positive words to others. While there is no significant relationship between convenience of website design and intentions of repeat e-dealing. And the electronic banking satisfaction does not play the role of mediator in influencing the relationship between E-CRM dimensions (expected security) and providing positive words to others, and the intentions to repeats electronic transactions. So, Managers are likely to increase customer's loyalty by providing technological protection mechanisms for electronic banking transactions and enhance convenience requirements on the website in terms of ease of use and immediate customer problem solving, predisposing positively Customer's attitudes towards the banks.
\end{abstract}

Corresponding author: Abdelaty Lasheen M. Mansi

Email addresses for the corresponding author: al mansi oal. @ yahoo.com

First submission received: 23rd May 2019

Revised submission received: 20 th August 2019

Accepted: $29^{\text {th }}$ August 2019

\section{Introduction}

Electronic banking services is closely linked to the customers' perception of security which has its impact on their trends and behaviors (Grabner and Faullant., 2008). With the continued provision of electronic banking services, commercial banks can ensure customers' satisfaction with banking services, which lead to achieve the Bank's electronic loyalty (Jamali, Mehrabadi and Pouri, 2017). Because the satisfied customer has the intention to repeat the electronic deal with the bank or provide positive words to others about the provider of electronic banking (Belás, Chocholáková and Gabčová, 2015). But the problems that faced the consumer in terms of security and privacy have led some individuals to be unwilling to use electronic transactions because of fear and concern about security issues and distrust of the benefits of online information systems (Winnie, 2014; Faraoni, Rialti, Zollo and Pellicelli, 2018). Security concerns can be addressed through the use modern technology protection methods (such as the site providing modern methods of encryption, protection of wires and cables used to connect devices to systems, and electronic websites offering security policies for protecting the privacy of information via the Internet(Poon, 2008). E-loyalty of Customer can be achieved by providing convenience in e-dealing; the home page contains links that make it easier for customers to complete various banking services through the bank's website (Amin, 2016). The availability of images and graphics work on the ease of use of 
banking transactions via the bank's website. (Lie'bana-Cabanillas, Munoz-Leiva and Rejon-Guardia, 2013; Bezhovski and Hussain, 2016). In addition, solving customer problems via the bank's website by providing online booklets, questions and answers to common problems, providing expert system in the bank's website via the Internet helps to achieve E-loyalty (Mang'unyi, Khabala, and Govender, 2017).

Although the impact of e-satisfaction on the dimensions of e-loyalty, in terms of the behavioral side of customers (Intending to repeat electronic transactions) and the emotional side (making positive recommendations to others about the service provider) (Kassim and Abdullah, 2010). little attention was paid to the factors that affect electronic satisfaction as one Precedents of electronic loyalty (Faraoni et al., 2018). So, This study is an attempt to measure the dimensions of E-CRM and to test the impact of its use on e-loyalty, while taking electronic banking satisfaction as Variable mediator, Where literature proved that e-satisfaction is the most influential factor in the role of mediation between the dimensions of E-CRM and e-loyalty, where Farhadi, Ghartemani, Ghartemani and Wastegany (2012) found that customer satisfaction affects the relationship between the dimensions of E-CRM and E-loyalty more than the empathy that attracts customers. While Mulyono and Situmorang (2018) found that E-satisfaction affects the relationship between the dimensions of E-CRM and E-loyalty more than previous experiences of edealing customers. So, this study attempts to answer the following research question, is security, privacy and availability of convenience in the use of online transactions affect e-loyalty through e-banking service satisfaction in Egyptian commercial banks?

\section{Literature review}

\subsection{Expected security and its impact on e-loyalty}

Customer E-loyalty is defined as intention of customer to reuse the banking services provided by the bank's website in the future (Amin and Fontaine, 2013).Customers who have an emotional relationship with an online service provider have the ability to overcome obstacles and intentions to replicate ebusiness and become as advocates for the organization (Faraoni et al. 2018). Customer loyalty increases when they feel that the information, they provide is confidential in addition to the confidence that online transactions are safe (Thaichon Lobo and Mitsis, 2014). Literature analyzes such concepts of E-loyalty by assuming that their main determinant is Expected security. More specifically expected security includes Trust in the website, Information quality and privacy of customer data, which are all three variables of customers attitudes and opinions toward an online transaction. Where Security is crucial to managing trust. As such, Trust in the website refers to is an attitude explain the opinion of the customer toward their confidence in online transaction (Faraoni et al. 2018). Information quality means information must be understandability, modern, consistency, sufficiency, relevancy and accuracy (Alim and Ozuem, 2014). Privacy is the protection of all customer data used during the completion of Online transactions (Kassim et al. 2010).

The Internet environment is most affected to system attacks (Dhillon and Torkzadeh, 2006). So, customers do not prefer online transactions because of fear of fraud or data leakage (Pavlou, Liang, and Xue, 2007). On the other side, when customers' expectations of the security level are met, they will be providing their personal data, and to continue their transaction (Faraoni et al. 2018). Customers will trust websites that protect their personal data and providing information about Security Policy (Galati, Crescimanno, Tinervia, and Fagnani, 2017). For banks to protect customer accounts and transactions, they must switch to E-CRM and uses modern security technologies (Miremadi, Ghalamakri and Ramezani, 2012).

According to studies conducted by different researchers, the shared opinion is that expected security antecedes E-satisfaction, where The Bank's Website ability to protect electronic banking transactions leads to satisfactory relationships with customer (Mang'unyi et al. 2017; Belás, Korauš, Kombo and korauš, 2016; Zavareh etal., 2012). Moreover, expected security is an antecedent to E-loyalty (Rialti, Zollo, Pellegrini and Ciappei, 2017; Mang'unyi, Khabala and Govender 2018; Faraoni et al. 2018). But, if the customer does not trust a website, he will not repeat the e-transactions even if he has quite satisfactory experiences (Anderson and Srinivasan, 2003). Ramseook-Munhurrun and Naidoo (2011) proved that the most important factors that involved in the customer's decision to stay and the electronic loyalty for the online stores is the expected security. Ismail and Safa (2014) confirmed that the most 
dimensions of Electronic customer relationship management affecting on e-loyalty compared to the Customization for online shopping customers are the technical factors that including the expected security. And the most dimensions of Electronic customer relationship management effecting on loyalty of customers to shop online compared to website design and easy access to the website is confidence then security expected (Özgüven, 2011). While Mang'unyi et al. (2018) conclude that there is a significant relationship between the dimensions of e-CRM (Privacy and security) and customer loyalty. This agreement among literature is indicates that availability expected security is the main reason for maintaining customers and not moving to alternative Websites (poon, 2008; Jamali et al. 2017). In addition to, the availability of trust in online banking is an important determinant of customer satisfaction with edealing with the bank (Liebana-Cabanillas et al. 2013).

Some previous studies have examined factors that reduce customer fears about online transaction security. The greater level of customer trust in electronic transaction leads to fewer concerns about customer privacy (Noor, 2012). while The studies of (Faraoni et al. 2018; leng 2008; Özgüven, 2011; kim, 2003) proved that the E-trust effect on E-loyalty of customers, due to the need for availability of trust requirements in the websites such as providing full information (leng, 2008), Reducing Illegal Disclosure of Customer Data (Noor, 2012; kim, 2003), Credibility (Gefen, 2002; Özgüven, 2011), Full protection of Customers money and The trust in security of electronic payments(Belás et al. 2016). Delivery on time (Noor, 2012) the customer's trust in the website leads to loyalty to brand and provide positive words to others about e-dealing (Rialti et al. 2017). And disagreed with them completely Valvi and West (2013) who proved that trust in the website does not affect the E-loyalty of the customer. This is since online customers are finding it difficult to reassure their Internet environment due to security concerns and the nature of non-personal relationships (Belás et al. 2016). And Customers who are aware of the risks of edealing are reluctant to deal online (Hanafizadeh and Khedmatgozar, 2012). Gefen (2002) emphasized that Lack of trust leads to reluctance customers to use banking online transaction.

Few academic studies have examined the factors contributing to develop an expected security from these studies. poon (2008) Confirmed that the accuracy, up to date content and credibility of the information lead to confidence in online banking and thus adopting e-banking services in Malaysia. Because websites consider an interface between companies and customers, it is important to provide information quality and the right type of information and good interactions that satisfy customers and creating customers' positive attitudes towards the website (Thaichon et al. 2014). Many researchers have studied influential factors of customer E-satisfaction and E-loyalty, while (Ismail et al. 2014; Winnie, 2014; Alhaiou, Irani and Ali, 2009) concluded that the quality of information provided by the website affects eloyalty of customer. Galati, Crescimanno, Tinervia, and Siggia (2016) suggested a website that provides abundant information and ensures good use can lead to positive consumption experience and consumer intent to repeat the purchase. In the context of online banking, providing updated information through the bank's website leads to increased customer satisfaction (Lie'bana-Cabanillas et al. 2013). And disagreed with them completely Liu, Tseng, Chuang and Huang (2012) who sees no correlation between the relevant information provided by the website and customer satisfaction and customer's electronic loyalty. We find that this may be due to the lack of this information to the accuracy; Modernity, clarity and interconnection which made it not affect the E-loyalty of customers. Similarly, the inaccuracy, up-todate contents and credibility of the information leads to a lack of confidence in online banking and hence the failure to adopt electronic banking services in Malaysia (poon, 2008). So, information quality is a unique dimension for Expected security.

Data privacy is one of the main concerns of the customer when dealing online, thus When the security level that the customers expects is achieved, they will provide personal details and complete their purchases (Faraoni et al. 2018). Website with a clear, reliable and transparent privacy policy is led to building positive perceptions of service quality (Thaichon et al. 2014). And Studies (kim, 2003; Clifford and Lang, 2012; Leng, 2008) have confirmed that protection of the privacy of customer data effect on Eloyalty of customer. And disagreed with them completely Peikari (2010) who confirmed that customer privacy does not affect E-satisfaction and E-loyalty, because the Internet environment Effect negatively on customers because of security concerns and the extent of protection of information systems. Thus, Low 
ability of banks to protect customer privacy in terms of confidential financial information is not kept securely, makes customers do not trust the bank's security policy and lose confidence in the performance Of online financial transactions (poon, 2008).

On the contrary, Murugiah and Akgam (2015) concluded an interesting result. They proved a negative relation between bank security and customer satisfaction. Where growth of bank security causes decreases in customer satisfaction. The reasons for that are complex bureaucratic procedures to increase security. Made the communication between bank and customers more difficult and thus Negative had effect on Satisfaction of customers. We conclude from the previous presentation that the expected security is one of the dimensions of the E- CRM that affects the electronic loyalty, and the expected security dimensions include the quality of information, trust and protect the privacy of customer data. Therefore, in this study it is hypothesized that:

H1: There is a significant relationship between the expected security from E- CRM and E-loyalty of customer.

This hypothesis is divided into the following sub- hypothesizes:

H1/1 There is a significant relationship between the expected security from the E-CRM and intentions to repeat electronic dealing.

H1/2 There is a significant relationship between the expected security from E-CRM and Provide customers with positive word of mouth for others.

Marketing researchers have placed emphasis on the relationships between expected security and banking E-satisfaction, and banking E-satisfaction and E-loyalty (Jamali et al. 2017; Kassim et al. 2010; Mang'unyi et al. 2017; leng, 2008) The shared opinion is that can be concluded that there is a significant relationship between The expected security and E- loyalty of customer through banking E-satisfaction. On the contrary Mang' unyi et al. (2018) proved that customer satisfaction has not affect on the relationship between dimensions of e-CRM (Privacy and security) and customer loyalty. While Özgüven (2011); Faraoni et al. (2018) believed that the security and Privacy of transactions affect customer loyalty but through E-Trust. It ended the dispute between the two teams Alhaiou et al. (2009); Ismail et al. (2014) who tested the relationship between expected security and customer loyalty through electronic satisfaction and electronic trust and found that the impact of electronic satisfaction on e-loyalty Greater than the impact of electronic trust. While Valvi et al. (2013) shows that there is no correlation relationship between e-trust and e-loyalty at websites of books selling in Britain, but there is a strong correlation between electronic satisfaction and e-loyalty. And Kassim et al. (2010) Proved that trust does not affect the intentions of repeat e - dealing and provide customers with positive word of mouth for others about e-dealing In Malaysia and Qatar. Therefore, in this study it is hypothesized that:

H2 There is a significant relationship between the expected security from E- CRM and E-loyalty of customer through electronic banking satisfaction. This hypothesis is divided into the following two subhypotheses:

H2/1 There is a significant relationship between the expected security from the E-CRM and intentions to repeat electronic dealing through electronic banking satisfaction.

H2/2 There is a significant relationship between the expected security from E-CRM and Provide customers with positive recommendations for others through electronic banking satisfaction.

\subsection{Convenience of website design and its impact on e-Satisfaction and e-loyalty}

While exploring the dimensions E-CRM which represent the antecedents of e-loyalty, other factors also need to be explored. The importance of convenience of website design has been greatly examined. Especially, a consumer's successful online banking transactions experience is affected by Problem solving (Mang'unyi et al. 2018). And ease use website (Kassim et al. 2010). Such elements, then, may positively influence consumer perception of e-Dealing with the bank, and, in turn, may influence eloyalty (Mang' unyi et al. 2018). So, understanding the factors that enhance web site quality is important to the success of online service provider (Thaichon et al. 2014). Ease of navigation provides a good purchasing experience; the efficiency of a website allows customers to provide orders quickly, leading to higher satisfaction levels (Faraoni et al. 2018). Therefore, good site design had a positive impact on esatisfaction (Cyr, Kindra, and Dash, 2009). customers who find convenience in e-dealing with the bank in terms of ease of use of electronic banking and the availability of the possibility to solve the problems of 
customers immediately, leads to providing customers positive words of Mouth about e-dealing with the bank. So, in the latter, it can be said that in electronic banks the efficiency of website is the main driver for establishing long-term relationships between banks and their customers, followed by ease of use (Amin, 2016).

According to studies conducted by different researchers (Dolly and Pruthi, 2014; Clifford et al. 2012; Rosário, 2015; Bezhovski et al. 2016) Although Different application scope, it can be concluded that there is a significant relationship between the convenience of website design and the E- loyalty of the customers. Where the first Study was applied on a sample of online shopping customers. The second study was conducted by university students in Ireland who deal online and took the third sample of fashion industry customers in Spain. The fourth study included the samples of the operating managers in the banks and the ten customers from each bank. This agreement in the results is based on the fact that they used the same tool of measurement to measure the convenience of website design as one of the dimensions of E-CRM, where they depended on (answering customer inquiries, Follow customer complaints and comments, clarifying to customers how to access information). In fact, Mang'unyi et al. (2018) proved that There is a significant relationship between the dimensions of e-CRM (User friendliness, Problem solving) and customer loyalty. There is a positive relationship between availability of convenience requirements and care and service via the website through interactive contacts across the site (Mekkamol, Piewdang and Untachai, 2013). Although the scope of application differed between some studies and their agreement to select The research sample as Winnie, (2014) He took a sample Of customers of three E-websites in Malaysia, and study Valvi et al. (2013) Which was applied to customers that buying books online In the UK, and study Faraoni et al. (2018) Which was applied to students enrolled in the Management Master's Degree in Italy, but they confirm the same of result is no correlation between the design of website and E- Satisfaction and E-Loyalty of customer for shopping online. This agreement in the results among the researchers may be indicates the similarity the requirements convenience of customers who prefer to deal online.

And Saini and kumar (2015) they took the sample of online shopping customers in India and found that Dimension of convenience is less influential on E-loyalty of customers compared with trust and security. and we sees that this is due to the researchers divided the sample study to (who have PhD, university students, employees) who have a high level of education, and have computer skills and electronic dealing, so the availability of convenience in use website did not affect their loyalty for electronic transactions, but rather They are looking for the level of security and the extent of protection of personal information via the site.

Specifically, convenience of website design includes a set of elements that contribute to the maintenance of a good relationship with online customers. Where regulate online banking, easy accesses to E-banking information, convenient visual structure are advantages to influence customers Esatisfaction (poon, 2008). Where Bezhovski et al. (2016) finds that E-CRM works to provide convenience in self-service to customers where they no longer must wait to pay utility bills. Amin (2016) believes that the ease of using the websites of the banks in search and organizing information leads to increased Esatisfaction and E-loyalty of customer. While Rosário, (2015) finds that the ease of use of the website reduces the cost of research and time to processing transactions, and gives good impression for the customer, and making them want to stay and handle via website. Additionally, Ho and Lin (2010) Customers prefer website of the bank that enables them to complete online banking in a timely manner, correctly and respond promptly to their inquiries.

When E-CRM working properly, it helps customer to Problem solving (Noor, 2012). While studies Rahimiparvar (2012); Bezhovski et al. (2016); Dolly et al. (2016) found that Problem solving affects Eloyalty of customer. Where Rahimiparvar, (2012) concludes that enabling customers to solve their own problems without sending mail Or make a call Lead to enhance intentions to repeat electronic dealing .While Bezhovski et al. (2016) concluded that early response to customer queries, fast processing to errors, and solving their problems make customers feel satisfied and maintain long-term relationships. While Dolly et al. (2014) suggests that problem solving as one of the dimensions of E-CRM will affect the transaction cycle online. Olupot and Kituyi, (2013) conclude that an online help desk responsible for customer problems solving about a service lead to create a personal interaction with the organization. In 
the banking context, the ability of banking sites to solve customer problems, customer feedback services and to accommodate complaints and the presence of an online help desk leads to the adoption electronic banking services (poon, 2008). In the Thailand online web site context, sincere attention to customer inquiries and answering, and solving customer problems across the site affect the customer Satisfaction (Thaichon et al. 2014). And disagreed with them Mang' unyi et al. (2017), who proved that there is a weak correlation between problem solving as one of the dimensions of E-CRM and customer loyalty for online banking. Therefore, in this Study it is hypothesized that:

H3: There is a significant relationship between convenience of website design and E- loyalty of customer The main hypothesis was divided into two sub-hypotheses

H3/1 There is a significant relationship between convenience of website design and intentions to repeat electronic dealing for customers.

H3/2There is a significant relationship between convenience of website design and Provide customers with positive word of mouth for others.

According to studies conducted by different researchers (Rahimiparvar, 2012; Rosário, 2015; kim, 2003; Ismail et al. 2014) it can be concluded that there is a significant relationship between convenience in website design and electronic satisfaction, and which leads to achieving E-loyalty of customer. While (Ismail et al. 2014; Rahimiparvar, 2012) concluded that the convenience of using the web site is the most dimensions E-CRM which influence on electronic loyalty compared to customization and electronic channels. While kim (2003) suggests that the impact Website design on electronic satisfaction and which leads to achieving E-loyalty of customer More than the impact of customer service. Ease use of website affects E- satisfaction, and this in turn impacts intentions to repeat e-dealing and providing customers with positive word of mouth for others (Kassim et al. 2010). On the contrary Mang'unyi et al. (2018) suggested that customer satisfaction has not moderating effect between dimensions of e-CRM (Problem solving, User friendliness) and customer E-loyalty. While Rosário (2015) who confirm that the website design Effects on the E- loyalty of the customer more than indirect relationship through E- Satisfaction. Therefore, in this study it is hypothesized that:

H4 There is a significant relationship between the convenience of website design as one of the dimensions of E-CRM and E-loyalty of customer through electronic banking satisfaction. This hypothesis is divided into the following two sub- hypotheses:

H4/1 There is a significant relationship between the convenience of website design as one of the dimensions of E-CRM and intentions to repeat electronic dealing through electronic banking satisfaction.

$\mathrm{H} 4 / 2$ There is a significant relationship between the convenience of website design as one of the dimensions of E-CRM and providing customers with positive words for others through electronic banking satisfaction.

\section{Research methodology}

3.1 methodology

This research depends on structure equation modeling (SEM) to measure the variables of the study. Based on the scientific approach to building and developing Measurements in behavioral sciences (Arbuckle, J., 2013). Figure 1 illustrates The Proposed research framework of the study.

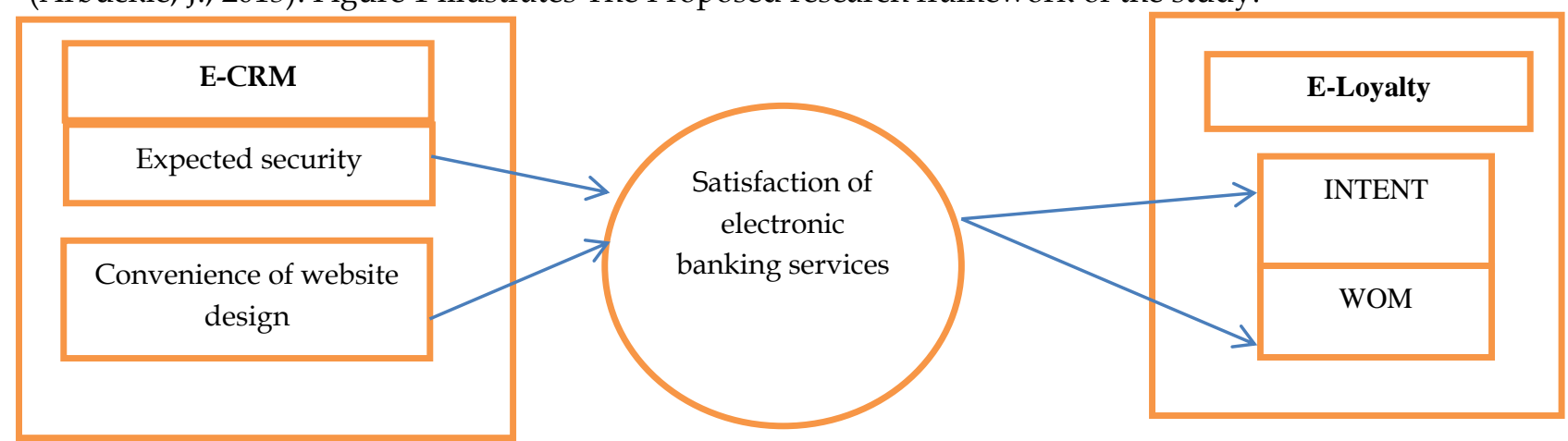

Figure 1. Proposed research framework 
Notes: E-CRM=Electronic customer relationship management, INTENT= intentions to repeat electronic dealing, WOM= word of mouth.

\subsubsection{Measuring variables}

First, a measurement model is designed to determine the significance of path coefficients

(Factor loadings) between multiple variables (observed variables) and (latent variables). It allows making sure the validity of the model. Next, a structural model is designed to verify the significance of statistical influences (or regression weights) that exist between the latent variables (Bentler, 1990), enabling testing of the causal Relationships between the variables that were hypothesized in the proposed conceptual model (see appendix).

\subsubsection{The questionnaire design}

A Questionnaire was designed to measure the dimensions of E- CRM (expected security and convenience of website design), the satisfaction of electronic banking services, the dimensions of ELoyalty (intention to repeat e-dealing and Provide customers with positive words for others). A selfadministered questionnaire was used to collect data from the online banking customers. The questionnaire is divided into three parts the first part: demographic data (age, gender, level of education, number of years of e-dealing with the bank). The second part deals with information about expected security and convenience of website design, while the third part is the electronic banking satisfaction and intentions to repeat electronic dealing with the bank and provide customers with positive words to others. On the Likert scale where $1=$ not at all influential and $5=$ extremely influential. All items in this questionnaire were adapted by previous studies (see appendix) expected security was based on (Ribbink, van Riel, Liljander and Streukens 2004; Poon, 2008; Vlachos and Vrechopoulos, 2008; Kim and Niehm 2009).The convenience of website design was based on (Herington and Weaven, 2009; Ho etal, 2010; Mang' unyi et al. 2017). Electronic banking satisfaction (six related items) The measurement was based on (Herington et al. 2009; Ribbink et al. 2004), E- loyalty (ten related items) included measures from a scale by (Ribbink et al. 2004; Gremler ,1995; Zeithaml, Berry and Parasuraman, 1996; Ramseook and Naidoo,2011).

\subsubsection{Sampling and data collection}

The research population consisted of all customers of Commercial banks in Cairo, Egypt. Customers who using Internet technology- based applications provided by the bank to access their services, a convenience sampling technique was employed to collect data by using questionnaire, Convenience sampling designs, generally, have been embraced in service marketing and social science research (Etikan, Musa and Alkassim, 2016) . Before these surveys, a pilot survey was conducted In November 2018 on a test sample of five subject matter experts, And Ten customer of commercial banks who e-dealing with the bank, who were asked to make written comments on clarity of the questions and length of the survey. The purpose of the pre-test of Questionnaire was to ensure a logical arrangement, readability and Credibility of the data collection instruments from a qualitative point of view (Hair Jr, Black, Babin , Anderson and Tatham, 2006), after changes were incorporated into the final questionnaire, a total of 384 questionnaires were distributed and collected, but only 370 were useable for analysis. Questionnaires were distributed randomly, and in person, to every customer came to the bank during business hours and who online transaction with the bank and those visiting the automatic teller machines (ATM) located outside the bank through the period between January 2019 and April 2019.

It is noted from the sample results that the category most interacting electronically with banks is male, where they represented $65.6 \%$ of the sample while females only $34.3 \%$. As for the variable age, it was found that the category (from 30 years to less than 40 years) represents the highest percentage in the sample of the study where it reached $80.8 \%$. This is a logical result as the youth group is the most receptive to the idea of dealing with banks and that was agreed with the views of the same study obtained by the researcher from personal interviews with customers in commercial banks. The high qualification is the highest percentage of the total sample $(70 \%)$, followed by a postgraduate $(23.51 \%), 93.51 \%$ of the total sample representing a high level of education. this refers to that individuals with higher educational level prefer to deal with electronic banks compared to individuals with lower educational level, which may be due to the high level of awareness and technological skills to them, In addition to the less educated 
category often have a fear from the risk of dealing electronically with banks As for the number of years of online transaction with the bank, it was found that the category (4 years to 6 years) represented the highest percentage of the total sample (43.5\%) followed by the category (from one year to 4 years). And its percentage $(24 \%)$ of the sample of the study. It refers to the sample has relatively high level of experience in dealing with the bank.

\section{Data analysis}

Include characteristics of sample, exploratory factor analysis (EFA), and reliability assessment of measures (stability), the Confirmatory Factor Analysis (CFA), Standard Direct Effect and Standard Indirect by using Bootstrap method.

\subsection{Measurement model}

\begin{tabular}{|c|c|c|c|c|c|}
\hline & EFA & CFA & $\mathrm{CR}$ & Cronbach's alpha & AVE \\
\hline sec1 & .662 & .731 & & & \\
\hline $\sec 2$ & .599 & .635 & & & \\
\hline $\sec 3$ & .709 & .741 & & & \\
\hline $\sec 4$ & .763 & .558 & & & \\
\hline $\mathrm{sec}$ & & 5651. & .71 & .70 & .61 \\
\hline conv1 & .530 & .783 & & & \\
\hline Conv2 & .781 & .582 & & & \\
\hline conv3 & .525 & .663 & & & \\
\hline Conv4 & .772 & .718 & & & \\
\hline conv & & 2.346 & 75. & .74 & .62 \\
\hline sati1 & .687 & .527 & & & \\
\hline sati2 & .745 & .709 & & & \\
\hline sati3 & .814 & .659 & & & \\
\hline sati4 & .669 & .666 & & & \\
\hline sati & & 2.361 & 79. & .78 & .55 \\
\hline INT1 & .510 & .555 & & & \\
\hline INT2 & .754 & .617 & & & \\
\hline INT 3 & .563 & .676 & & & \\
\hline INT 4 & .703 & .650 & & & \\
\hline INT5 & .516 & .600 & & & \\
\hline INTENT & & 2.44 & .78 & .77 & .63 \\
\hline wom1 & .506 & .677 & & & \\
\hline Wom2 & .835 & .761 & & & \\
\hline Wom3 & .711 & .681 & & & \\
\hline Wom4 & .752 & .560 & & & \\
\hline wom & & 2.679 & .81 & .80 & .61 \\
\hline
\end{tabular}

Table 1: exploratory factor analysis, Confirmed Factor Analysis, Composite Reliability, Cronbach's Alpha and Average Variance Extracted

Notes: $\operatorname{conv}=$ Convenience of website design, $\sec =$ Expected security, sati $=$ Banking Electronic Satisfaction, INTENT= intention to repeat e-dealing, wom = Provide customers with positive words, AVE: Average Variance Extracted; CR: Composite Reliability.

The dimensions of the study were analyzed using oblique rotation through exploratory factor analysis (EFA), The criterion of meaningful factor loading was set to 0.4 according to (Tsoukatos and Rand, 2006). Cronbach's alpha test was estimated to determine the internal consistency of the Study variables (Hair, Black, Babine and Anderson, 2010). Table 1 refers to that the values Cronbach's alpha ranged between .70 and .80, which were acceptable it above $50 \%$ according to (Nunnally, 1978). Confirmatory Factor Analysis (CFA) was used to test the measurement model, the factor loading was range between (0.52 to 0.78), being larger than or close to 0.6 (Bagozzi and Yi, 1988; Hair Jr et al. 2006). To assess the internal consistency of study indicators, we assessed the composite reliability (CR) for each latent variable. All variables such as Expected security (0.71), Convenience of website design (0.75), 
Electronic Banking Satisfaction (0.79), intention to repeat e-dealing (.78), Provide customers with positive words (0.81). Its show acceptable levels of CR, over 0.6 according to (Bagozzi et al. 1988). For Convergent validity was estimated by the average of variance extracted index (AVE). AVE of Expected security (0.61), Convenience of website design (0.62), Electronic Banking Satisfaction (0.55), intention to repeat e-dealing (.63), provide customers with positive words (.61). It's showed acceptable values being higher than 0.50 according to (Fornell and Larcker, 1981).

Also, Average Variance Extracted (AVE) uses as tool to evaluate Discriminant validity, through the comparison between AVE and correlation coefficient values between factors, should be (AVE) Greater than (correlation) ${ }^{2}$ according to (Fornell et al. 1981).

\begin{tabular}{|c|c|c|c|c|c|c|}
\hline \multirow[t]{2}{*}{ Factor name } & correlation & \multirow[t]{2}{*}{$\mathrm{sec}$} & \multirow[t]{2}{*}{ conv } & \multirow[t]{2}{*}{ sati } & \multirow[t]{2}{*}{ INTENT } & \multirow[t]{2}{*}{ wom } \\
\hline & AVE & & & & & \\
\hline \multirow[t]{3}{*}{ sec } & correlation & & & & & \\
\hline & AVE & & & & & \\
\hline & (correlation)2 & & & & & \\
\hline \multirow[t]{3}{*}{ conv } & correlation & .55 & & & & \\
\hline & AVE & .61 & & & & \\
\hline & (correlation)2 & .302 & & & & \\
\hline \multirow[t]{3}{*}{ sati } & correlation & .28 & .34 & & & \\
\hline & AVE & .56 & .57 & & & \\
\hline & (correlation)2 & .078 & .115 & & & \\
\hline \multirow[t]{3}{*}{ INTENT } & correlation & .43 & .51 & .22 & & \\
\hline & AVE & .62 & .63 & .61 & & \\
\hline & (correlation)2 & .184 & .260 & .048 & & \\
\hline \multirow[t]{3}{*}{ wom } & correlation & .38 & .44 & .11 & .49 & \\
\hline & AVE & .63 & .63 & .54 & .61 & \\
\hline & (correlation)2 & .144 & .193 & .012 & .240 & \\
\hline
\end{tabular}

All correlations are significant at $\mathrm{p}<0.01$ (two-tailed)

Table 2 the comparison between AVE and correlation coefficient values

Based on the results shown in the previous table, (AVE) values for each factor are greater than the (correlation coefficient) ${ }^{2}$ of the same factor, which confirms the achieved Discriminant validity of all factors in the proposed measurement model.

\section{Testing of hypotheses}

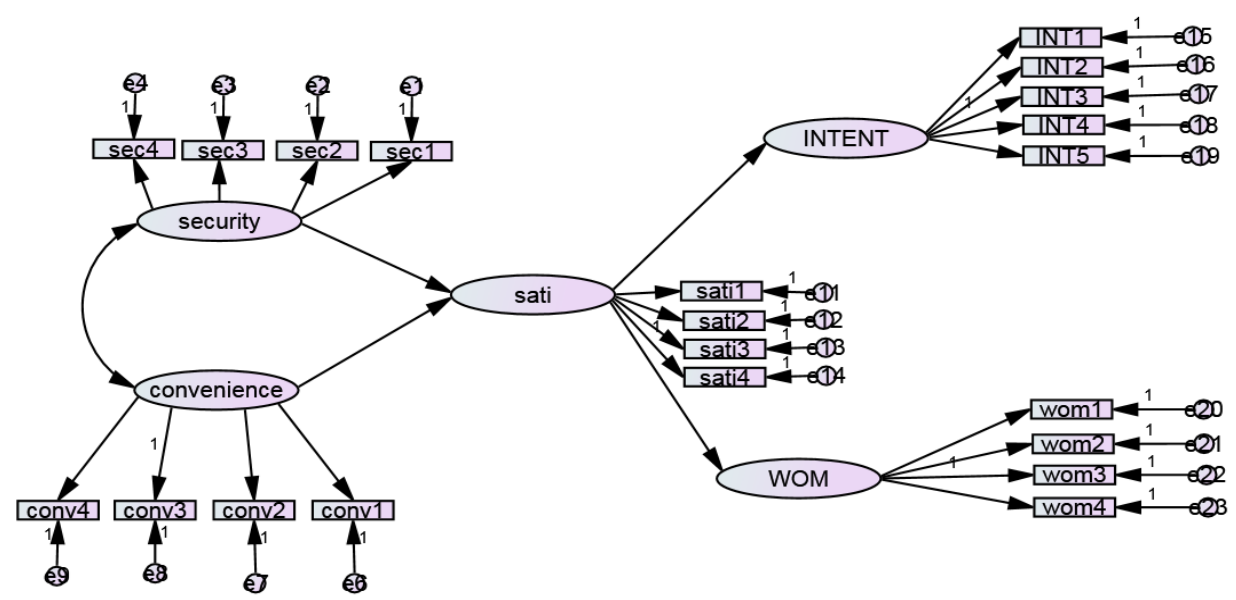

Figure (2) the structural model of the study 


\begin{tabular}{|l|l|l|}
\hline Measures & Fit Indices & Threshold Values \\
\hline CMIN/DF & 1.6 & Less than 3 \\
\hline GFI & 0.99 & 0.90 and above \\
\hline AGFI & 0.96 & 0.90 and above \\
\hline CFI & 0.99 & 0.90 and above \\
\hline TLI & 0.98 & 0.90 and above \\
\hline NFI & 0.98 & 0.90 and above \\
\hline RMSEA & 0.05 & Less than 0.08 \\
\hline
\end{tabular}

Table (3) Results of the quality indicators of conformity of the structural model of the study (model fit)

For each of the main dimensions (Expected security, Convenience of website design, Electronic Banking Satisfaction, intention to repeat e-dealing, provide customers with positive words) a CFA was estimated using the SPSS module AMOS v. 22 (Arbuckle, 2013). The hypotheses were tested using a structure equation modeling (SEM) because this technique provides statistical efficiency and its ability to assess the relationships comprehensively (Hair et al. 2006). Moreover, SEM techniques are particularly appropriate for the study of multiple relationships between variables such as those investigated in this research. The previous table shows that the modified construction model is the best solution where all the indicators of conformity are acceptable, where CMIN / DF (1.8) are less than 2. The "goodness-of-fit index" (GFI) measures the fit between the hypothesized model and the covariance matrix of the observed variables, proposing values near to 0.90 as an acceptable model fit (Hu and Bentler, 1999). The GFI of the model (0.98), and the related "adjusted goodness-of-fit index" (AGFI) (0.96), suggested an acceptable model fit. The "root mean square error of approximation "(RMSEA), which measures the fit of the tested model with the population covariance matrix, (.05) is less than (0.08). It was calculated because of their robustness, stability, and lack of sensitivity to sample size (Hair et al. 2006). "Comparative fit index" (CFI), and the "normed fit index" (NFI) is estimated according to (Bentler, 1990). According to Hu et al. (1999) CFI and NFI Results of above 0.95 are good. The hypothesized model indicated acceptable fit indices of $\mathrm{CFI}=0.97$ and NFI=0.94. Which confirms the validity of the measurement model, and good conformity for the sample data of the research.

To Test the hypotheses of the study and investigate that there is significant relationship between the dimensions of the E-CRM and The E-loyalty by checked value of Critical Ratio For Regression Weight(CR) Between each independent factor affecting the dependent variable In a table of Regression Weights, and (CR) must be More than(+/- 1.96). The following table shows Summary of results of Regression Weights Between the dimensions of E-CRM (the expected security, convenience of website design) and the intention to repeat the electronic E-dealing provide positive words to others.

\begin{tabular}{|lll|rrrrr|}
\hline & & & Estimate & S.E. & C.R. & P & Label \\
\hline wom & $<---$ & sec & .105 & .051 & 2.058 & .038 & \\
wom & $<---$ & conv & .330 & .092 & 3.596 & $* * *$ & \\
INTENT & $<---$ & sec & .432 & .198 & 2.181 & .029 & \\
INTENT & $<---$ & conv & -.178 & .119 & -1.495 & .135 & \\
\hline
\end{tabular}

Table (4) Regression Weights: (Group number 1 - Default model)

Through The results shown in the previous table:

The hypothesis(H1/1) was accepted, a value of $\mathrm{CR}=2.181$ (i.e. more than1. 96) that indicate to the effect of independent variable on the dependent variable is significant, and (Estimate $=0.432$ ) with a positive sign indicating that there is a positive relationship between the expected security and the intentions of E-dealing with the bank, the greater of the level of availability of security that customers expect by one, the more customers will offer positive words to others about e-dealing with the bank by (0.432) and the value of $P=.029$ (i.e. less than 0.05) This indicates the relationship between the expected security and intention to repeat e-dealing is significant.

The hypothesis(H1/2) was accepted, a value of $\mathrm{CR}=2.058$ (i.e. more than 1.96) that indicate to that the effect of the independent variable on the dependent variable is significance, (Estimate $=.105$ ) with a positive sign indicating that there is a positive relationship between the expected security and 
providing positive words to others, and The greater of the level of availability of security that customers expect by one, the more customers will offer positive words to others about e-dealing with the bank by (0.105), $(P=0.038)$, i.e., less than (0.05). This indicates the relationship between the expected security and providing positive words to others is significant.

We show that the availability of security in the bank's website in terms of the protection of credit card information, the providing of Passwords secure, lead to increased customer satisfaction for electronic dealing, The availability of confidence in the site in terms of clarity of information and credibility Encourage customers to speak well about e-dealing with the bank.

The hypothesis $(\mathrm{H} 3 / 1)$ was rejected. The value of $(\mathrm{CR}=-1.495)$ was less than $(1.96)$ indicating that there was no effect of the independent variable on the dependent variable, and the value of $(P=.135)$ which shows the relationship between the availability of convenience of website design and the intention to repeat e-dealing with the bank is not significant.

The hypothesis $(\mathrm{H} 3 / 2)$ was accepted, because a value of $(\mathrm{CR}=3.596)$, which is more than $(1.96)$ that indicate to the effect of independent variable on the dependent variable is significant, and (Estimate $=$ 0.330) with a positive sign indicating that there is positive relationship between convenience of website design and providing positive words, the more convenience of website design by one, the more customers offer positive words to others about the electronic deal with the bank( by 0.330$)$, and the value of $(\mathrm{P}=* * *)$ Indicates the relationship between the convenience of website design and provide customers with positive words to others about dealing with the bank is significant.

We confirm that through interviews with customers of commercial banks that the organization of information in terms of arrangement of banking services available through the bank's website leads to the completion of transactions easily and quickly, because increasing the Entry of customers on the bank's page causing pressure on the server, and thus slowness of the process Browsing.

\section{Standardized Direct Effect and Standardized Indirect Effect by Using the Bootstrap method:}

To test hypothesis H3, Mediator variable test through Bootstrap method

\begin{tabular}{|c|c|c|c|c|c|c|c|}
\hline \multicolumn{3}{|c|}{ Variables } & \multirow{2}{*}{$\begin{array}{c}\text { Direct path } \\
\text { coefficient } \\
\text { value }\end{array}$} & \multirow[t]{2}{*}{ significant } & \multirow{2}{*}{$\begin{array}{c}\text { Indirect path } \\
\text { coefficient } \\
\text { value }\end{array}$} & \multirow[t]{2}{*}{ significant } & \multirow{2}{*}{$\begin{array}{l}\text { Total path } \\
\text { coefficient } \\
\text { value }\end{array}$} \\
\hline Independent & Mediator & dependent & & & & & \\
\hline $\begin{array}{l}\text { expected } \\
\text { security }\end{array}$ & $\begin{array}{l}\text { E-banking } \\
\text { Satisfaction }\end{array}$ & $\begin{array}{l}\text { intention } \\
\text { repeat E- } \\
\text { dealing }\end{array}$ & .357 & $* * *$ & .021 & $* * *$ & .378 \\
\hline $\begin{array}{l}\text { convenience } \\
\text { of website } \\
\text { design }\end{array}$ & $\begin{array}{l}\text { E-banking } \\
\text { Satisfaction }\end{array}$ & $\begin{array}{l}\text { intention } \\
\text { repeat E- } \\
\text { dealing }\end{array}$ & -.561 & .201 & .014 & .013 & -.547 \\
\hline $\begin{array}{l}\text { E-banking } \\
\text { Satisfaction }\end{array}$ & - & $\begin{array}{l}\text { intention } \\
\text { repeat E- } \\
\text { dealing }\end{array}$ & .163 & - & .000 & - & .163 \\
\hline
\end{tabular}

Table (5) Results of the direct, indirect and total relationship of the study variables

Source: by researcher based on the results of statistical analysis.

The previous table Show that: There is a significant effect between the (expected security) and the intentions repeat $\mathrm{E}$ - dealing. Where the value of the beta coefficient was $\left.\mathrm{p}={ }^{* * *}\right)$. And the relationship between convenience of website design and the intentions repeat E- dealing is not significance, where the value of the beta coefficient was greater than (0.05).

The study Found that a direct impact between (expected security) and intentions of repeat edealing. Greater than the indirect effect between (expected security) and intentions of repeat e-dealing. This indicates that banking E-Satisfaction does not play the role of mediator in influencing on the relationship between E-CRM dimensions (expected security) and intentions to repeat e-dealing Thus rejecting $(\mathrm{H} 2 / 1)$. The indirect effect between convenience of website design and intentions of repeat edealing was found to be greater than the direct effect between convenience of website design and intentions of repeat e-dealing. This indicates that banking E-Satisfaction as a mediator variable in influencing the relationship between E-CRM dimensions (convenience of website design) and the intentions to repeat e-dealing. And thus accept (H4/1). 


\begin{tabular}{|c|c|c|c|c|c|c|c|}
\hline \multicolumn{3}{|c|}{ Variables } & \multirow{2}{*}{$\begin{array}{l}\text { Direct path } \\
\text { coefficient } \\
\text { value }\end{array}$} & \multirow{2}{*}{ Significant. } & \multirow{2}{*}{$\begin{array}{l}\text { Indirect } \\
\text { path } \\
\text { coefficient } \\
\text { value }\end{array}$} & \multirow{2}{*}{ significant } & \multirow{2}{*}{$\begin{array}{l}\text { Total path } \\
\text { coefficient } \\
\text { value }\end{array}$} \\
\hline Independent & Mediator & dependent & & & & & \\
\hline $\begin{array}{l}\text { expected } \\
\text { security }\end{array}$ & $\begin{array}{l}\text { E-banking } \\
\text { Satisfaction }\end{array}$ & $\begin{array}{l}\text { Providing } \\
\text { positive } \\
\text { words to } \\
\text { others. }\end{array}$ & .531 & .033 & $\begin{array}{l}-.103 \\
\end{array}$ & .136 & .428 \\
\hline $\begin{array}{l}\text { convenience } \\
\text { of website } \\
\text { design }\end{array}$ & $\begin{array}{l}\text { E-banking } \\
\text { Satisfaction }\end{array}$ & $\begin{array}{l}\text { Providing } \\
\text { positive } \\
\text { words to } \\
\text { others. }\end{array}$ & .284 & $* * *$ & .063 & .107 & .347 \\
\hline $\begin{array}{l}\text { E-banking } \\
\text { Satisfaction }\end{array}$ & - & $\begin{array}{l}\text { Providing } \\
\text { positive } \\
\text { words to } \\
\text { others. }\end{array}$ & .436 & - & .000 & - & .436 \\
\hline
\end{tabular}

Source by researcher based on the results of statistical analysis:

Table (6) Results of the direct, indirect and total relation of variables

Previous table Show that: There is a significant effect between (expected security, convenience of website design) and provides positive words for others. Where the value of beta coefficient less than (0.05).

The direct effect between (expected security, convenience of website design) and provides positive words to others was found to be greater than the indirect effect between (expected security, convenience of website design) and providing positive words to others. Which shows that electronic banking satisfaction does not play the role of mediator in influencing the relationship between E-CRM dimensions and providing positive words to others. And thus reject $(\mathrm{H} 2 / 2),(\mathrm{H} 4 / 2)$.

\section{Discussions}

Customers' e-loyalty considers a competitive advantage for commercial banks. So, this research contributes to the exploration of the primary factors that attract Electronic loyalty of customers of commercial banks. Our study has found that there is a positive relationship between expected security and electronic loyalty, which corroborates with previous research (Faraoni et al. 2018). Unlike in previous studies Murugiah et al. (2015) who stressed on There is a negative relationship between expected security and Satisfaction of customers due to the complicated procedures followed by banks to protect customer privacy. so, The main contribution of the research is that commercial banks providing the levels of security that customers expect in terms of fulfilling their promises, providing high security features, maintaining the information quality and timely provision of relevant information, lead to encouraging customers to share details of credit card and renewing intentions of electronic dealing with the bank and urging others to use electronic banking transactions.

The second contribution is that the study found that there is a significant relationship between convenience in website design and providing positive words of mouth to others about electronic dealing. This result agreed with (Amin, 2016) the efficiency of website is the main driver for establishing long-term relationships between banks and their customers. And Mang'unyi et al. (2018) proved that there is a significant relationship between the dimensions of e-CRM (User friendliness) and Encourage customers to providing positive words of mouth to others about electronic dealing. This result disagreed with (Valvi et al. 2013) who confirmed that there is no correlation between the design of website and E-Loyalty of customer. So, when the bank website is easy to use and well organized, it encourages customers to talk well about the advantages of electronic dealing with the bank. While the lack of online brochures to help customers solve their problems and the lack of an expert system to help customers complete their banking transactions, making it difficult to use online banking, which is reflected in the low intentions to repeat electronic transactions with the banks.

On the other hand, electronic satisfaction does not play the role of mediator in influencing the relationship between E-CRM dimensions (expected security, convenience of website design) and providing positive words to others. And the similarity of that with previous research, Mang'unyi et al. 
(2018) suggested that customer satisfaction has not moderating effect between dimensions of e-CRM (Problem solving, User friendliness) and customer E-loyalty. Unlike in previous studies, there is a significant relationship between the expected security and E- loyalty of the customer via banking Esatisfaction (Kassim et al. 2010). Therefore, the bank needs to enhance the areas of customer dissatisfaction in terms of the ability of the site to provide the needs of the client before the deadline or on time, informs customers of new offers constantly, make e-banking services exceed customer expectations. While electronic satisfaction does not act as a mediator in the impact on the relationship between the dimensions of E-CRM (the expected security) and the intention to repeat e-transactions. While electronic satisfaction does act as a mediator in the impact on the relationship between the dimensions of E-CRM (the convenience) and the intention to repeat e-transactions.

\section{Conclusion}

This study provides additional evidence to the marketing literature concerning the impact of ECRM on e-loyalty. This study contributes by highlighting some factors that have not been widely examined in literature such as, banking E-satisfaction, expected security and convenience of design website.

Although this study has proved that E-CRM effects on decrease customer intention to switch to other website and increase customer E-loyalty, the relationship between customers and the bank's website largely depends on the availability of secure E-banking transactions. Therefore, commercial banks need to increase customer confidence in electronic banking transactions by protecting the privacy of data and maintaining the quality of information provided via the bank's website. For this reason, Miremadi et al. (2012) highlights that bank managers must take action that will raise customer confidence towards online banking transactions. Similarly, Customers are reluctant to e-dealing with the bank if they don't trust in electronic banking (Belás et al. 2016). Thus, to increase customer confidence in electronic banking transactions, the customer must be proactively notified that online transactions are kept confidential. As well as provide guidance on how to solve security problems and information on how to use online banking in a secure way (Amin 2016). The current study shows that banks should announce the security policy they follow in detail through the bank's website. It agreed with poon (2008) who stressed that the lack of adequate information on security measures for electronic banking services reduces customers' reliance on electronic banking services.

Regarding the convenience of e-dealing with the bank, it was found that there is a significant relationship between the convenience of website designing and provides positive recommendations to others. Which requires commercial banks to provide the bank's website with well-organized information, and the home page contains links that make it easier for customers to complete various transactions, in addition to the availability of images and graphics work on the ease of completion of transactions and reduce customer effort. Similarly, When the organization's website is attractive, convenient and friendly, it leads to increased customer loyalty (Valvi et al. 2013).

\section{Managerial implications}

From the customer's point of view, according to the results of this research, it is clear that in Egyptian commercial banks, attention should be given to electronic customer relationship management as an antecedent to E-loyalty, especially, the Security that customers expect an banks websites should be given a top priority. In the context of electronic banking, trust is a characteristic element (Belás etal. 2016). Investments focused on enhancing confidence should be increased, information transparency, the management of the customer's relationship. All limitations, terms of online promotions, payment procedures, site use policies should be made explicit (Faraoni et al. 2018). Therefore, websites of commercial banks should provide clear, easy-to-understand and highly credible information about how to complete electronic banking transactions to minimize errors in electronic transactions. The Bank's website must be presents information about its security policies to protect the privacy of customer data, and keeps credit card information secure, leading to renewed intention to repeat e-dealing with the bank, and Do not think about switching to another bank. It would also be advantageous to link this information to tips for using e-banking services securely. This study contributes to increasing the understanding of commercial bank managers of the needs of customers in terms of convenience requirements in electronic dealing (ease 
of use and problem solving) and security levels (confidence in the site, quality of information and privacy protection). Commercial bank managers are advised to focus on providing customers with positive words to others by ensuring that the bank's website is comfortable and user friendly. Simplifying online banking transactions to reduce Working pressure in branches and improve the bank's reputation reinforcing customers' intent to repeat e-dealing. Commercial banks can also enhance their intentions to deal with the bank by aiding customers to solve banking problems.

\section{Limitations and Trends of Future Research}

The model of study was tested in the Egyptian commercial banks context which may be not only different from other service sectors but also in other countries. This study has found that banking Esatisfaction does not mediate the relationship between dimensions E-CRM and e-loyalty. And thus, opens the field for future researches to support these results or variation with them and relying on other intermediate variables such as electronic trust. For future research, additional E-CRM dimensions should be investigated such as Perceived Value.

\section{References}

Arbuckle, J. (2013), Amos 22. User's Guide, Small waters Corporation, Chicago, IL.

Alim, S and Ozuem, W, (2014), the Influences of e-CRM on Customer Satisfaction and Loyalty in the UK Mobile Industry, Journal of Applied Business and Finance Researches, Volume 3, Issue 2: pp 47- 54.

Amin, M., Isa, Z. and Fontaine, R. (2013), "Islamic banks: contrasting the drivers of customer Satisfaction on image, trust, and loyalty of Muslim and non-Muslim customers in Malaysia", International Journal of Bank Marketing, Vol. 31 No. 2, pp. 79-97.

Amin, M, (2016),"Internet banking service quality and its implication on e-customer satisfaction and e-customer loyalty", International Journal of Bank Marketing, Vol. 34 Iss 3 pp. 280 - 306.

Anderson, R.E. and Srinivasan, S.S. (2003), "E-satisfaction and e-loyalty: a contingency framework", Psychology \& Marketing, Vol. 20 No. 2, pp. 123-138.

Alhaiou, T, Irani, Z, Ali, M, (2009), the relation between e-CRM implementation and E- Loyalty at different adaptation stages of transaction cycle: conceptual fram work Hypothesis, European and Mediterranean Conference on Information Systems, pp. 440-452.

Bagozzi, R.P. and Yi, Y. (1988), "On the evaluation of structural equation models", Journal of the Academy of Marketing Science, Vol. 16 No. 1, pp. 74-94.

Belás, J, Chocholáková, A., Gabčová., L. (2015), Satisfaction and loyalty of banking customers: A Gender approach, Economics and Sociology, Vol. 8, No 1, pp. 176-188. DOI: 10.14254/2071-789X.2015/8-1/14.

Belás, J.; Korauš, M.; Kombo, F.; Korauš. A. (2016), Electronic banking security and customer satisfaction in commercial banks, Journal of Security and Sustainability Issues 5(3): 411-422.

Bezhovski, Z, Hussain, F, (2016), the Benefits of the Electronic Customer Relationship Management to the Banks and their Customers, Research Journal of Finance and Accounting, Vol.7, No.4.

Bentler, P.M. (1990), "Comparative fit indexes in structural models", Psychological Bulletin, Vol. 107 No. 2, pp. 238246.

Cyr, D., Kindra, G. and Dash, S. (2008), Website Design, Trust, Satisfaction, and e-Loyalty: The Indian Experience. Online Information Review, 32(6), 773-790.

Dhillon, G.; Torkzadeh, G. (2006), Values-focused assessment of information system security in Organizations, Information Systems Journal, Vol. 16, No. 3, pp. 293-314.

Dolly, Pruthi, A (2014), E-CRM Framework: Service to Customer Perspective, International Journal of Advanced Research in Computer Science and Software Engineering, Volume 4, Issue 4, pp 1363-1366.

Clifford, D, Lang, M, (2012), What Determines E-Loyalty? An Analysis of Factors Affecting online Customer Retention, Vol. 10, pp. 9-21.

Etikan, I., Musa, S. A., and Alkassim, R. S. (2016), Comparison of Convenience Sampling and Purposive Sampling. American Journal of Theoretical and Applied Statistics, 5, 1-4. https://doi.org/10.11648/i.ajtas.20160501.11.

Faraoni, M, Rialti, R, Zollo, L and Pellicelli, A.C (2018), "Exploring e-Loyalty Antecedents in B2C

e-Commerce: Empirical results from Italian grocery retailers", British Food Journal, https:// doi.org/10.1108/BFJ-04-2018-0216.

Farhadi F, Ghartemani, S.K, Ghartemani, H.K, Wastegany, J.R, (2012), Analyzing the Effects of e-CRM on customers Loyalty: A case study of Parsmodir Khazar Enterprise, Advanced Research in Economic Management Sciences (AREMS) Vol.7.

Fornell, C. and Larcker, D.F. (1981), "Evaluating structural equation models with unobservable variables and measurement error", Journal of Marketing Research, Vol. 18, pp. 39-50. 
Galati, A., Crescimanno, M., Tinervia, S. and Siggia, D. (2016), “Website quality and internal business factors: an empirical investigation in the Italian wine industry", International Journal of Wine Business Research, Vol. 28 No. 4, pp. 308-326.

Galati, A., Crescimanno, M., Tinervia, S. and Fagnani, F. (2017), “Social media as a strategic marketing tool in the Sicilian wine industry: evidence from Facebook", Wine Economics and Policy, Vol.6No. 1, pp. 40-47.

Gefen, D. (2002), “Customer loyalty in e-commerce”, Journal of the Association for Information Systems, Vol. 3 No. 1, pp. 27-51.

Grabner-Krauter, S.; Faullant, R. (2008), Consumer acceptance of internet banking: the influence of internet trust. International Journal of Bank Marketing, Vol. 26, No. 7, pp. 483-504.

DOI:10.1108/02652320810913855.

Gremler, D.D., (1995), The effect of satisfaction, switching costs, and interpersonal bonds on Service loyalty. Doctoral Thesis. Arizona State University.

Hanafizadeh, $\mathrm{p}$ and Khedmatgozar, H, R, (2012), The mediating role of the dimensions of the perceived risk in the effect of customers' awareness on the adoption of Internet banking in Iran, Electronic Commerce Research, 12, PP 151-175.

Herington, C. and Weaven, S. (2009), “E-retailing by banks: e-service quality and its importance to customer satisfaction", European Journal of Marketing, Vol. 43 Nos 9/10, pp. 1220-1231.

Ho, C.-T.B. and Lin, W.-C. (2010), "Measuring the service quality of internet banking: scale Development and validation", European Business Review, Vol. 22 No. 1, pp. 5-24.

Hair, J.F., Black, W.C., Babin, B.J. and Anderson, R.E. (2010), Multivariate Data Analysis: A Global Perspective, Pearson Prentice Hall, New York, NY.

Hair Jr, J.F., W.C. Black, B. Babin, R. Anderson and R. Tatham. (2006), Multivariate Data Analysis, 6th edn., PrenticeHall, Upper Saddle River, NJ.

Hu, L.T. and Bentler, P.M. (1999), "Cutoff criteria for fit indexes in covariance structure analysis: conventional criteria versus new alternatives", Structural Equation Modeling A Multidisciplinary Journal, Vol. 6 No. 1, pp. 1-55.

Kassim, N and Abdullah, N.A, (2010), The effect of perceived service quality Dimensions on

customer satisfaction, trust, and loyalty in e-commerce settings: A Cross cultural analysis, Asia Pacific Journal of Marketing and Logistics, Vol. 22 Iss: 3 pp. 351 - 371.

Ismail, M.A, and Safa N S, (2014), Trust, Satisfaction, and Loyalty Formation in Electronic Commerce, Journal of Industrial and Intelligent Information Vol. 2, No. 3.

Jamali, M, Mehrabadi, M.A, Pouri, M, (2017), The Effect of the Implementation of E-CRM Electronic Satisfaction and Loyalty, Electronic Consumers of Mellat Bank's Website, Special Edition Journal, Vol.19, pp.117-135.

kim, J, (2003), an integrative model of E-loyalty development process: the role of E- satisfaction, E-trust, tail quality and situational factors, Master thesis.

Kim, H, Niehm, L.S,(2009), The Impact of Website Quality on Information Quality, Value, and Loyalty Intentions in Apparel Retailing, Journal of Interactive Marketing 23(3):221- 233.

Lie'bana-Cabanillas, F, Munoz-Leiva, F, Rejon-Guardia, F, (2013), The determinants of satisfaction with e-banking, Industrial Management \& Data Systems, Vol. 113 No. 5, pp. 750-767.

Liu, C, Tseng, H, Chuang, L, Huang, C, (2012), A Study of the Impact of the e-CRM Perspective on Customer Satisfaction and Customer Loyalty-Exemplified by Bank Sinopac, Journal of Economics and Behavioral Studies, Vol. 4, No. 8, pp. 467-476.

leng, T.Y, (2008), internet banking service quality and E- loyalty in Penang, Malaysia, Master thesis.

Mulyono, H, Stammering, S.H, (2018), E-CRM and loyalty: A mediation Effect of Customer Experience and satisfaction in online transportation of Indonesia, Acadimac Journal of Economic studies, vol 4, No 3, pp 96105.

Mang'unyi, E. E., Khabala, T. O. and Govender, K. K. (2017), “The relationship between e-CRM and customer loyalty: a Kenyan commercial bank case study", Bank and Bank Systems, Vol. 12 No. 2, pp.106-115, http://dx .do i.org/10.21511/bbs.12(2).2017.11.

Mang'unyi E .E, Khabala,T.O and Govender,K.K (2018), "Bank Customer Loyalty and Satisfaction: The Influence of Virtual e-CRM", African Journal of Economic and Management Studies, https://doi.org/10.1108/AJEMS-082017-0183.

Mekkamol, P, Piewdang, S, Untachai, S, (2013), Modeling e-CRM for Community Tourism in Upper Northeastern Thailand, Social and Behavioral Sciences Symposium, 4th International Science, Social Science, Engineering and Energy Conference, vol 88108 - 117, doi: 10.1016/j.sbspro.2013.08.486.

Murugiah, L.; Akgam, H.A, (2015), Study of Customer Satisfaction in the Banking Sector in Libya, Journal of Economics, Business and Management, Vol. 3, No. 7 pp. 674-677. 
Miremadi, A, R, Ghalamakri, S and Ramezani, A.A, (2012), Challenges in Trust and Security by Implementation of ECRM among Banks and Financial Institution: A Case Study Of E-Banking in Iran, International Journal of Information Science and Management, Special Issue.

Nunnally, J.C. (1978), Psychometric Theory, Vol. 2, McGraw-Hill, New York, NY.

Noor, N. A. M, (2012) Trust and Commitment: Do They Influence E- Customer Relationship Performance? International Journal of Electronic Commerce Studies, Vol.3, No.2, pp. 281-296, doi: 10.7903/ijecs.1096.

Olupot, C. and Kituyi, G.M. (2013), “A framework for the adoption of electronic customer Relationship management information systems in developing countries", The Electronic Journal in Electronic Systems in Developing Countries, Vol. 58 No. 3, pp. 1-19.

Özgüven, N, (2011), Analysis of the Relationship Between Perceived Security and Customer Trust and Loyalty in Online Shopping, Chinese Business Review, Vol. 10, No. 11, pp 990-997.

Pavlou, P.A., Liang, H. and Xue, Y. (2007), “Understanding and mitigating uncertainty in online Relationships: a principal-agent perspective", MIS Quarterly, Vol. 31 No. 1, pp. 105- 136.

Peikari, H.R, (2010), The Influence of Security Statement, Technical Protection, and Privacy on Satisfaction and Loyalty; A Structural Equation Modeling, Springer, pp. 223-231.

Ramseook-M., P. and Naidoo, P. (2011), “Customers' perspectives of service quality in internet banking", Services Marketing Quarterly, Vol. 32 No. 4, pp. 247-264.

Poon, W, (2008), Users' adoption of e-banking services: the Malaysian perspective, Journal of Business and Industrial Marketing, Vol $23 \cdot$ NO 1, PP 59-69.

Rahimiparvar, N, (2012), E-CRM features that affect customer attitude E- loyalty: A case Study of sample of 402 university study enrolled in international programs inThailand.

Rialti, R., Zollo, L., Pellegrini, M.M. and Ciappei, C. (2017), “Exploring the antecedents of brand loyalty and electronic word of mouth in social-media-based brand communities: do gender differences matter?", Journal of Global Marketing, Vol. 30 No. 3, pp. 147-160.

Ribbink, D., van Riel, A.C.R., Liljander, V. and Streukens, S. (2004), “Comfort your online customer: quality, trust, and loyalty on the internet", Managing Service Quality, Vol. 14 No. 6, pp. 446-56.

Rosário, J. d, (2015), E-loyalty in e-commerce: A study at girissima.com, doctoral Thesis.

Saini, G. S, and Kumar, S, (2015), The Effect of e-CRM on Customer Satisfaction: An Empirical Study of Online Shopping, Journal of Management and Science, Vol.5. No.2.

Thaichon, P, Lobo, A, and Mitsis, A, (2014), an empirical model of home internet services quality in Thailand, Asia Pacific Journal of Marketing and Logistics, Vol. 26 No. 2.

Tsoukatos, E. and Rand, G.K. (2006), "Path analysis of perceived service quality, satisfaction and loyalty in Greek insurance", Managing Service Quality, Vol. 16 No. 5, pp.501-19.

Winnie, P.W, (2014), The Effects of Website Quality on Customer e-Loyalty: The Mediating Effect of Trustworthiness, International Journal of Academic Research in Business and Social Sciences, Vol. 4, No. 3.

Valvi, A. C., West, D. C. (2013), E-loyalty is not all about trust, price, also matters: Extending expectation-confirmation theory in book selling web sites, Journal of Electronic Commerce Research, vol 14, No 1.

Vlachos, A. and Vrechopoulos, P. (2008), "Determinants of behavioral intentions in the mobile internet services market", Journal of Services Marketing, Vol. 22 No. 4, pp. 280-291.

Zavareh, F., Ariff, M., Jusoha, A., Zakuan, N., Bahari, A. and Ashourian, M. (2012), “E-service quality dimensions and their effects on e-customer satisfaction in internet banking services", The 2012 International Conference on Asia Pacific Business Innovation and Technology Management, Procedia - Social and Behavioral Sciences, Vol. 40, pp. 441-445.

Zeithaml, V.A., L.L. Berry and A. Parasuraman, (1996), "The Behavioral Consequences of Service Quality," Journal of Marketing, Vol. 60, No. 2:31-46. 


\section{Appendix A:}

\begin{tabular}{|c|c|c|}
\hline $\mathrm{NO}$ & Questionnaires & references \\
\hline \multirow[t]{3}{*}{ expected security } & $\begin{array}{l}\text { Trust: } \\
\text {-I am prepared to give private information to online banks. } \\
\text { - I am willing to give my credit card number to most online banks. } \\
\text { - Online banks always fulfill their promises. }\end{array}$ & (Ribbink et al., 2004) \\
\hline & $\begin{array}{l}\text { Privacy: } \\
\text {-Confidential information is delivered safely from banks to customers. } \\
\text {-Continuous improvement on online systems. } \\
\text {-The website has high security features. }\end{array}$ & (Poon, 2008) \\
\hline & $\begin{array}{l}\text { Quality of information: } \\
\text {-The website provides high quality information. } \\
\text {.The website provides timely information- } \\
\text {-The website provides relevant information. }\end{array}$ & $\begin{array}{l}\text { (Vlachos etal., 2008; Kim teal., } \\
\text { 2009) }\end{array}$ \\
\hline \multirow[t]{2}{*}{$\begin{array}{l}\text { convenience of } \\
\text { website design }\end{array}$} & $\begin{array}{l}\text { Ease use: } \\
\text {-The website of online banks is simple to use. } \\
\text {-The website of online banks is well organized. } \\
\text {-I can get on to the website of online banks quickly. } \\
\text {-Pages at the website of online banks do not freeze. } \\
\text {-It is easy to find what I need on the website of online banks. } \\
\text {-I can complete a transaction quickly on the website of online banks. }\end{array}$ & $\begin{array}{l}\text { (Herington etal., 2009; and Ho } \\
\text { etal., 2010) }\end{array}$ \\
\hline & $\begin{array}{l}\text { problems solving } \\
\text {-the Bank provides brochures via internet that help customers solve } \\
\text { their problems. } \\
\text {-The bank provides questions and answers via internet to common } \\
\text { problems. } \\
\text {-There is an expert system via the bank's website that helps customers } \\
\text { solve their problems. }\end{array}$ & (Mang' unyi et al., 2017) \\
\hline $\begin{array}{l}\text { Electronic Banking } \\
\text { Satisfaction: }\end{array}$ & $\begin{array}{l}\text {-I am generally pleased with the Banking's online services. } \\
\text {-I am very satisfied with the Banking's online services. } \\
\text {-I am happy with the online Banking. } \\
\text {-The website of the online Banking is enjoyable. } \\
\text {-The website of online banks is simple to use. } \\
\text {-I am satisfied with overall online bank's products and services. }\end{array}$ & $\begin{array}{l}\text { (Herington etal.,2009; Ribbink et } \\
\text { al. 2004) }\end{array}$ \\
\hline \multirow[t]{2}{*}{$\begin{array}{l}\text { E-Loyalty } \\
:\end{array}$} & $\begin{array}{l}\text { Intentions to Repeat E-dealing: } \\
\text {-I seldom consider switching to another Web site. } \\
\text {-If the present service continues, I doubt that I would switch Web sites. } \\
\text {-I try to use the Web site whenever I need to make a purchase. } \\
\text {-When I need to make a purchase, this Web site is my first choice. } \\
\text {-I like using this Web site. } \\
\text {-I intend to continue using the online Banking. } \\
\text {-I prefer the online Banking above others. }\end{array}$ & $\begin{array}{l}\text { (Gremler1995; Zeithaml et al. 1996; } \\
\text { Ribbink et al. 2004) }\end{array}$ \\
\hline & $\begin{array}{l}\text { Providing positive words to others: } \\
\text {-I would recommend the Bank's website to others. } \\
\text {-I would like to say positive things about online banking to other } \\
\text { people. } \\
\text {-I would recommend online banking to someone who seeks advice. }\end{array}$ & $\begin{array}{l}\text { (Ribbink et al. 2004; } \\
\text { Ramseooketal., 2011; Zeithaml et } \\
\text { al., 1996) }\end{array}$ \\
\hline
\end{tabular}

